\title{
NEW TAXONOMIC AND FAUNISTIC DATA ON THE DUSTY WINGS FROM SENEGAL (INSECTA, NEUROPTERA, CONIOPTERYGIDAE)
}

\author{
V. J. Monserrat*
}

\begin{abstract}
New data on the taxonomy, biology, distribution and/or morphology of eight dusty wing species from Senegal are given. None had previously been recorded from this country. In this African area (where the Afrotropical and Palaearctic Biogeographical Regions contact) a great number of species can be found, mostly afrotropical elements, but also some palaearctic elements and species with a wide circumsaharan distribution are present. A great faunistic similarity between the Senegalese Fauna and the SW Arabian Peninsula fauna is noted, and both areas show many common elements present in the East-West Afrotropical northern borders. Some new synonymies are proposed as follow: Aleuropteryx felix Meinander, $1977=$ (Aleuropteryx teleki Sziráki, $1990=$ Aleuropteryx transvaalensis Meinander, 1998), Aleuropteryx arabica Meinander, 1977 $=($ Aleuropteryx cruciata Sziráki, 1990), Coniocompsa silvestriana Enderlein, $1914=$ (Coniocompsa arabica Sziráki, 1992 = Coniocompsa fimbrata Tjeder, 1957), Coniopteryx (Coniopteryx) greenpeace Monserrat, $1995=($ Coniopteryx (Coniopteryx) sclerotica Meinander, 1998), Coniopteryx (Xeroconiopteryx) triantennata Monserrat, $1995=($ Coniopteryx (Xeroconiopteryx) sestertia Meinander, 1998) and Nimboa marroquina Monserrat, 1985 = (Nimboa manselli Meinander, 1998). Also a replacement name: Coniopteryx (Xeroconiopteryx) conviventibus nom. nov. is proposed for Coniopteryx (Xeroconiopteryx) furcata Meinander, 1998 nec Coniopteryx (Scotoconiopteryx) furcata Meinander, 1983.
\end{abstract}

Key words: Neuroptera, Coniopterygidae, Afrotropical, Senegal, taxonomy, biogeography.

\section{RESUMEN}

Nuevos datos sobre la taxonomía y la faunística de los coniopterígidos de Senegal (Insecta, Neuroptera, Coniopterygidae)

Se anotan nuevos datos sobre la taxonomía, biología, distribución y /o morfología de ocho especies de coniopterígidos recolectados en Senegal. Ninguna de ellas había sido citada en este país. Al igual que ocurre en el SO de la Península Arábiga, esta zona del Continente Africano (donde confluyen las Regiones Biogeográficas Afrotropical y Paleártica) es especialmente rica en especies, la mayoría son afrotropicales, pero también están presentes algunos elementos paleárticos y otros de amplia distribución circumsahariana. Se anota una marcada similitud faunística entre ambas zonas con elementos comu-

\footnotetext{
* Departamento de Zoología y Antropología Física. Facultad de Biología. Universidad Complutense, 28040 Madrid (Spain).
} e-mail: ARTMAD@bio.ucm.es 
nes que alcanzan las zonas septentrionales que al este y el oeste limitan la Región Afrotropical. Se proponen como nuevas sinonimias a: Aleuropteryx felix Meinander, 1977 $=($ Aleuropteryx teleki Sziráki, $1990=$ Aleuropteryx transvaalensis Meinander, 1998), Aleuropteryx arabica Meinander, $1977=$ (Aleuropteryx cruciata Sziráki, 1990), Coniocompsa silvestriana Enderlein, $1914=($ Coniocompsa arabica Sziráki, $1992=$ Coniocompsa fimbrata Tjeder, 1957), Coniopteryx (Coniopteryx) greenpeace Monserrat, $1995=$ (Coniopteryx (Coniopteryx) sclerotica Meinander, 1998), Coniopteryx (Xeroconiopteryx) triantennata Monserrat, $1995=($ Coniopteryx (Xeroconiopteryx) sestertia Meinander, 1998) y Nimboa marroquina Monserrat, 1985 = (Nimboa manselli Meinander, 1998) y se propone un nombre de reemplazo a: Coniopteryx (Xeroconiopteryx) conviventibus nom. nov. para Coniopteryx (Xeroconiopteryx) furcata Meinander, 1998 nec Coniopteryx (Scotoconiopteryx) furcata Meinander, 1983.

Key words: Neuroptera, Coniopterygidae, Afrotropical, Senegal, taxonomía, biogeografía.

\section{Introduction}

The family Coniopterygidae is one of the most interesting in the order Neuroptera due to its almost cosmopolitan geographical distribution, high number of species (almost 450) and specimens which its populations usually consist, and in particular for its importance in the control of small phytophagous pests (Meinander, 1972, 1990; New ,1989; McEwen et al., 2001; etc.).

It is accepted that the best known dusty wings fauna is the European, followed by the Western Palaearctic, Afrotropical and remaining regions (Meinander, 1972, 1990; Aspöck et al., 1980, 2001; Aspöck \& Hölzel, 1996, etc.). Related to the Afrotropical fauna and from the first records by Enderlein (1906), new data and descriptions have been published on its Palaearctic and Afrotropical Regions that Meinander (1972) revised. Later articles have been published after this revision that Meinander (1990) summarized, and recent articles by Meinander (1992, 1996, 1998a, b), Sziráki (1990, 1994), Sziráki \& Greve (1996), Monserrat (1995, 1998, 2002), Ohm \& Hölzel (1997, 1998, 1999), Hölzel \& Ohm (1990) and Hölzel et al. (1999) have contributed to the knowledge of the African dusty wings. Many biogeographical interesting aspects on the relationships among Palaearctic, Afrotropical and Oriental dusty wings fauna have been reported by Hölzel \& Ohm (1990), Aspöck \& Hölzel (1996), Monserrat (1995, 1996, 2002), Meinander (1996), Sziráki (1998) and Hölzel (1998).

All these papers have contributed new data on biology, taxonomy, morphology, variability, distribution and biogeography, but in most of the species the level of knowledge is still very limited, and the degree of intra-specific variability is probably wide and still underestimated (Aspöck \& Hölzel, 1996; Meinander, 1996, 1998a).
Thus, the general knowledge about this continent is still very unsatisfactory and fragmentary, especially in the circumsaharan countries and in the West Afrotropical area because most of dusty wings records belong to the Mediterranean area, and to the East and South areas. From the existing bibliographical data can be noticed the scarceness of articles related to Saharan Central and West Africa, where only a few records from Guinea Conakry, Saharan Democratic Republic, Mali, Senegal, Ghana, Togo and Nigeria can be found.

In this article, we contribute new data on the taxonomy, geographical distribution, biology, morphology and/ or variability of some species of this family from Senegal, which presumptive poor dusty wings fauna had been particularly reported, and where only two species: Coniocompsa fimbrata Tjeder, 1957 and Coniopteryx lindbergi Tjeder, 1957 were previously recorded (Ohm \& Hölzel, 1984; Hölzel \& Ohm, 1990).

\section{Material and methods}

The recorded material was collected at sea level

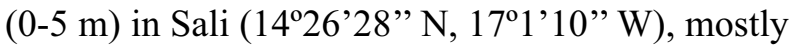
at light, during three samplings nights (25-27 August 2004), but some other material collected on arboreal vegetation is also reported. For each of the eight collected species a previously known geographic distribution and recorded plant substrate are noted. The general taxonomy, systematic and terminology used for the different species is that used for this family by Meinander $(1972,1990)$.

The proposed synonymies are not only based in the recent and very good original descriptions of the species proposed as synonymies (where data on its general morphology and genitalia are adequately figured and reported) that made unneces- 
sary the study of its type series, but also in our own criteria and experience on afrotropical dusty wings (African and SW Arabian Peninsula faunas) as much as many other previously studied material by author, not recorded in this contribution. Data of such information, opinions and studied material are recorded in the discussions and in the cited references.

The material remains in the author's collection in the Complutense University of Madrid.

\section{Results}

Aleuropteryginae Enderlein, 1905

Aleuropterygini Enderlein, 1905

\author{
Aleuropteryx felix Meinander, 1977: 81 \\ = Aleuropteryx teleki Sziráki, 1990: 120 n. syn. \\ = Aleuropteryx transvaalensis Meinander, 1998a: 119 n. syn.
}

A species known from Yemen, very scarcely recorded, and with an almost unknown biology, collected at light and on Tamarix. The now recorded new specimen agrees well in its external pigmentation, morphology, numbers of flagellomers (21) and genitalia with data reported for this species by Meinander (1977).

As some other species described from Africa and Asiatic Afrotropical areas (Arabian Peninsula: Yemen and Saudi Arabia) that we cite in this contribution, we can now conclude that some other African species and some other species previously considered as vicariate African and Asiatic Aleuropteryx described species are really the same taxa. In our opinion this specimen agrees with data recorded for Aleuropteryx teleki Sziráki, 1990 (described from a single specimen from Tanzania), and with Aleuropteryx transvaalensis Meinander, 1998 (described from two specimens from South Africa) and we think that Sziráki (1990) and Meinander (1998a) are giving different descriptions of the same species. According with Meinander (1996, 1998a) who even suggested some of the new synonymies now proposed, the differences noted by Sziráki (1990) seem scarcely sustainable for a genus with very uniform basic male structures, but with a certain morphological variability on these genital structures, and these new synonymies are now proposed.

Aleuropteryx felix has a wide Afrotropical distribution (Fig. 1) and, as Meinander (1990) and Aspöck et al. (2001) suggested, we also think that it is probable that Aleuropteryx wawrikae Rausch \&
Aspöck, 1978, known from Morocco, may be conspecific with this species.

SENEGAL: Sali, 0 m, 25-27 August 2004, $1 \sigma^{\pi}$ at light, V. J. Monserrat.

The same biogeographical and taxonomic problem occurs with other three species of the same genus, all described on a single specimen, and with a very similar morphology and analogous geographical distribution: Aleuropteryx arabica described by Meinander (1977) from Arabia and recorded from Yemen and Oman, Aleuropteryx cruciata described by Sziráki (1990) from Tanzania and Aleuropteryx dorsalis described by Meinander (1998a) from Botswana.

We think that the differences noted (and later maintained) by Sziráki (1990, 1992) seem scarcely sustainable, and a new synonymy, suggested by Monserrat (1996), is now proposed:

Aleuropteryx arabica Meinander, 1977: 83

= Aleuropteryx cruciata Sziráki, 1990: 117 n. syn.

As the previous mentioned species, Aleuropteryx arabica must also have a wide and similar Afrotropical distribution.

We also think, as very probable, that Aleuropteryx dorsalis Meinander, 1998 may be conspecific with the now recorded species. In its description Meinander (1998a) compared it with the other species of the Aleuropteryx argentata Tjeder, 1957 group (sensu Meinander, 1972 Aleuropteryx species groups). However the male genitalia in both species (A. arabi$c a$ and A. dorsalis) are too similar (Meinander 1977, 1998a) as belong to two different species groups, and the unspotted forewings with unforked $\mathrm{CU}_{2}$ do not seems a very sustainable taxonomic characters (with some exceptions in this group division as in A. furcocubitalis Aspöck \& Aspöck, 1968, A. ressli Raush, Aspöck \& Ohm, 1978 or A. ohmi Meinander, 1998) to retain $A$. dorsalis into the $A$. argentata group, and not in the same A. minuta group where A. arabica was included (Meinander 1972, 1977, 1998a). Probably a new species ordination and new synonymies will be proposed in a near future.

\section{Coniocompsini Enderlein, 1905}

Coniocompsa silvestriana Enderlein, 1914: 226
$=$ Coniocompsa arabica Sziráki, 1992: 90 n. syn.
$=$ Coniocompsa fimbrata Tjeder, 1957a: 1 n. syn.

This species was inadequately described from Guinea Conakry by Enderlein (1914) and its type 


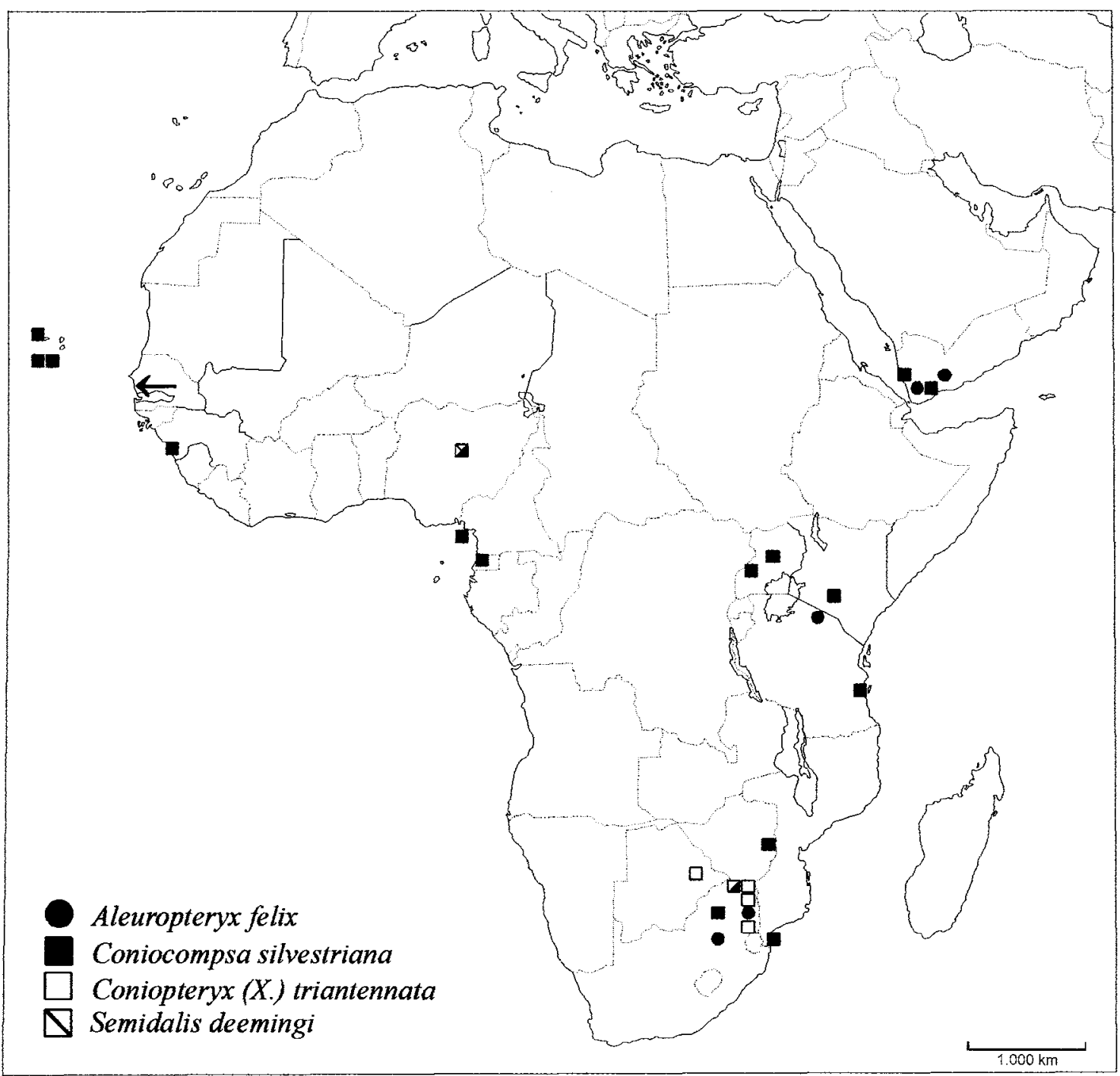

Fig. 1.- Previously known distribution of the afrotropical species now recorded in Senegal (arrow).

Fig. 1.- Distribución conocida de especies afrotropicales colectadas en Senegal (flecha).

deposition is still unknown. This species was redescribed by Meinander (1975a) on the basis of new samples from Nigeria, and later it was recorded from South Africa and Tanzania. Coniocompsa silvestriana was frequently associated with Coniocompsa smithersi Meinander, 1972 (Monserrat \& Díaz Aranda 1988; Monserrat 1989; Meinander 1996, 1998a), a species recorded from central and south Africa (Kenya, Zimbabwe, South Africa, Zambia and Equatorial Guinea), and finally it was synonymized by Monserrat (2002) who records it from Mozambique and Uganda. The new record in Senegal reports a wider Afrotropical distribution (Fig. 1).

The genus Coniocompsa Enderlein, 1905 has a wide paleo-tropical distribution. It has 15 actually recognized species, mostly described on the basis of a single specimen, with very slight differences among many of them, and sometimes only the female is known. The problematic situation on the taxonomy of this genus were already noted by Tjeder (1957a), Meinander (1972, 1975a, 1996, 1998a) or Monserrat \& Díaz Aranda (1988). Some synonymies 
have been suggested by Meinander (1972, 1982, 1996, 1998a), Monserrat \& Díaz Aranda (1988) or Monserrat (1989), and some was formally proposed (Monserrat, 2002).

As some other species described from Asiatic Afrotropical areas that we cite in this contribution, we can also conclude that some of the African and Asiatic Coniocompsa described species are really the same. So, after the study of abundant material of Coniocompsa silvestriana Enderlein, 1914 from different Afrotropical populations -material already recorded by Monserrat \& Díaz Aranda (1988) and Monserrat $(1989,2002)$ - and after to comparing them with the present new specimen, we can confirm the highly variable wing pigmentation (with individuals with almost clear wings to specimens with strongly dark spotted wings), male wings length (fore wings / hind wings: 1.9-3.0/1.7-2.6 $\mathrm{mm}$ in the African material, $2.14 / 1.87 \mathrm{~mm}$ in the new specimen recorded from Senegal and 2.6/2.4 $\mathrm{mm}$ in the material from Yemen), variable number of antennal segments $\left(\sigma^{7} /\right.$ : : 19-23/16-18 in the African material, 21/? in the new specimen recorded from Senegal and 23/? in the material from Yemen), as much as a real variability in their genitalia in this species (extensible to the genus and many of their species), and we conclude, as Monserrat \& Díaz Aranda (1988) and Meinander $(1990,1998 a)$ suggested, that some of the described differences, specially in the male genitalia, are no more than artefacts due to the different interpretations of authors, different positions in which genitalia were drawn, and differences in the degree of sclerotization of the male genitalia.

So, after such questions, we can conclude that the differences between Coniocompsa silvestriana Enderlein, 1914 and Coniocompsa arabica Sziráki, 1992, described and recorded from Yemen (Sziráki 1992, 1997; Hölzel 1998, and very probably Coniocompsa sp. recorded from Yemen by Meinander 1977) are, in our opinion, unsustainable to maintain two different taxa, and the new synonymy is proposed.

The same problematic exists with the other African species: Coniocompsa fimbrata Tjeder, 1957, a species known from Cabo Verde Islands (S. Vicente, Santiago, Fogo), which male genitalia has not yet been described, and with dark spotted wings, female fore / hind wings length: 2.00/1.85 $\mathrm{mm}$, and both antennae defective in the Type. It was suggested as the same species that Coniocompsa silvestriana by Meinander (1975a), but its isolated populations as results of its insularity have maintained it as a presumptive valid spe- cies from its description. The recent records of this species in Senegal by Ohm \& Hölzel (1984) and Hölzel \& Ohm (1990) -whom suggested a wider continental distribution for this species- and the morphology of the now recorded material of Coniocompsa silvestriana Enderlein, 1914 from this country, support the now proposed new synonymy. It is also very probably that some other Oriental species of this genus will bring us new synonymies in a future when new more material was studied.

The biology of this species is relatively well known. It was recorded from 0-1.965 m, at light and on Ficus capensis, Cynometra alexandri, Rinorea beniensis, Trichilia rubescens, Tecla nobilis, Rinorea ardisiifolia, Theobroma cacao, and on other unspecified arboreal vegetation. Monserrat $(1998,2002)$ noted interesting data about its feeding biology, similar to the now reported ones: the peritrophic membranes of the new specimen had fragments of Acari, Actinedida, Eriophyoidea: Eriophydae, rests of unidentified insects, and some pollen grains.

SENEGAL: Sali, 0 m, 27 August 2004, $1 \sigma^{7}$ on Melia azedarach L. (Meliaceae) V. J. Monserrat.

Coniopteryginae Burmeister, 1839

Coniopterygini Burmeister, 1839

Nimboa marroquina Monserrat, 1985a: 76

= Nimboa manselli Meinander, 1998a: 132 n. syn.

This species is known from Morocco, South Africa, Mozambique and Yemen. Its biology is almost unknown, mostly collected at light and sometimes recorded on Phoenix dactylifera.

The new west African (Senegal) specimens agree well with data noted by Monserrat (1985a, 1995) and an expansive circum Saharan wide distribution is confirmed (Fig. 2). The new male specimen has 22 flagellomers and in the females (21-22) the first one has a variable length, from similar length to other near flagellomers to that recorded by Monserrat (1985a).

The genus Nimboa Navás, 1914 is one of the most problematic in dusty wings. It has a wide distribution in the South West Palaearctic, Afrotropical and SW Oriental Regions. Actually it has 18 recognized species, some described on the basis of a single or a few specimens, sometimes the male genitalia is unknown, usually with very slight differences among many of them, and a great intraspecific variability have been recorded. As 


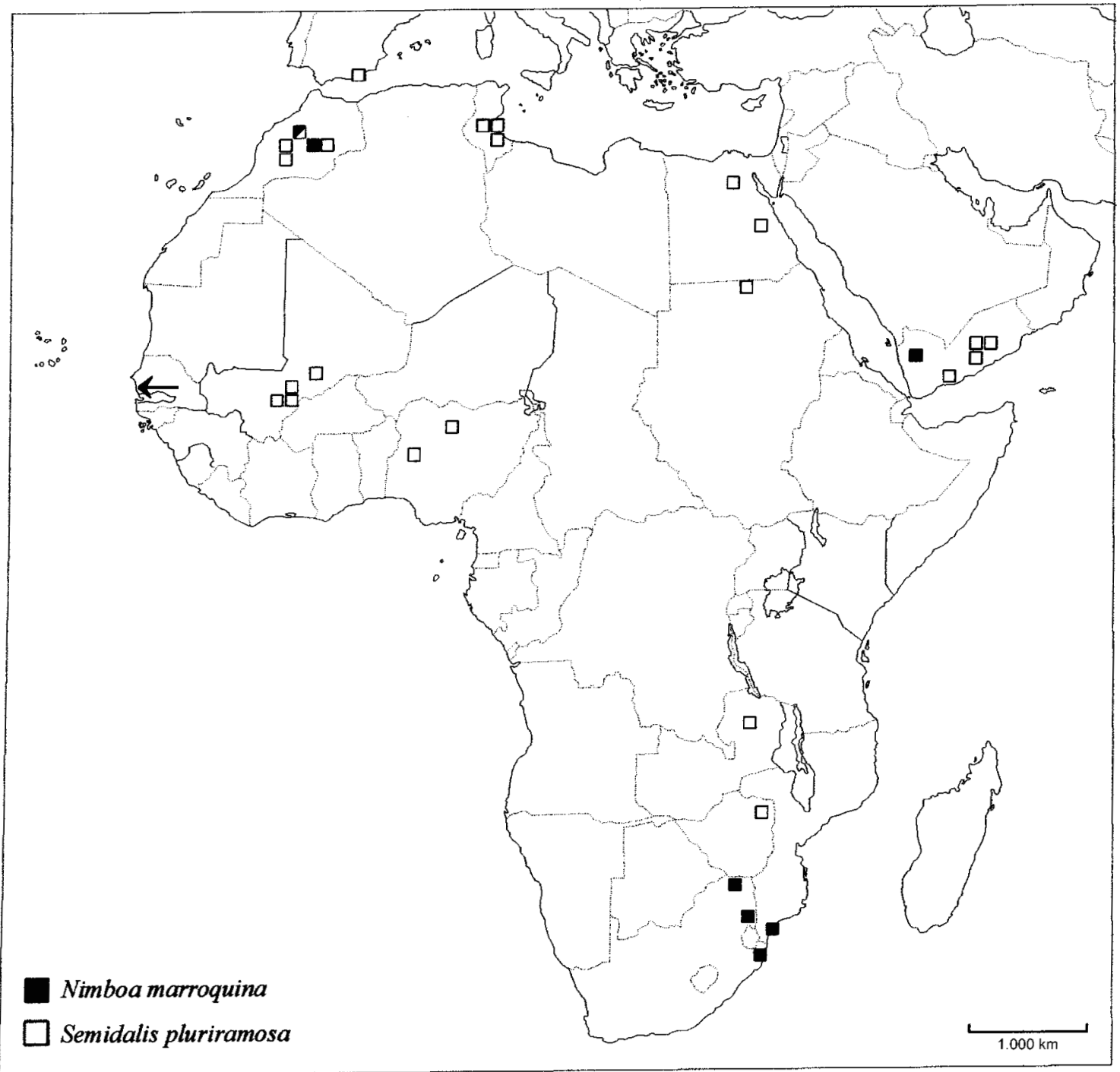

Fig. 2.- Previously known distribution of the circumsaharan species now recorded in Senegal (arrow).

Fig. 2.- Distribución conocida de especies circunsaharianas colectadas en Senegal (flecha).

Meinander (1996, 1998a) noted, and we agree, some of the described differences in the male genitalia of many species in this genus are no more than artefacts, owing to different interpretations of authors, different positions in which genitalia were drawn, and intra-specific variability. It is also very probable that some other detected differences as the degree of sclerotization of their genitalia and the more or less wings pigmentation are consequence of the age of the specimens. These taxonomic questions were already noted by Tjeder (1957b),
Meinander (1972, 1996, 1998a), Monserrat (1998) or Aspöck et al. (2001). Some synonymies have been suggested by Meinander (1972, 1996, 1998a), or Monserrat (2002), and some were formally proposed (Meinander 1972, 1998a; Monserrat 1995).

In our opinion, the differences between Nimboa manselli described by Meinander (1998a) from South Africa and Nimboa marroquina, also recorded from South Africa, even from similar collecting places and dates (Monserrat 1995; Meinander 1998a) seem scarcely sustainable, and the morpho- 
logy of the new specimens fall within the common morphology of both taxa. A new synonymy, already discussed and suggested by Monserrat (2002) is now formally proposed, and new material will bring us a more clear taxonomic position on the wings spotted afrotropical Nimboa species, and probably some wings spotted Nimboa spp. (Meinander, 1975a, 1983a, 1998a; Hölzel et al., 1999) will come into this synonymy group, and also some other Nimboa species described from Asia and from African and Asiatic Afrotropical Region will provide new synonymies.

The abdomen of the now collected specimens contained many fat drops, and the gut and the peritrophic membrane abundant fragments of adults and nymphs of Acari, Actinedida, Eriophyoidea: Tydeidae, Rhyncaphytoptidae and Ereynetidae, fragments of unidentified insects, some pollen grains and fungi hyphae.

SENEGAL: Sali, 0 m, 25-27 August 2004, $10^{7}, 1$ 우 at light, 27 August 2004, 1 o on Melia azedarach L. (Meliaceae) V. J. Monserrat.

Coniopteryx (Xeroconiopteryx) ketiae Monserrat, 1985

Species described from dry areas in the SE of Spain and recorded from Yemen. The new west African records (Senegal) agree well with data noted by Monserrat (1985b) and confirm a wider south west Palaearctic distribution in this species (Fig. 3) as Sziráki (1997) suggested.

The biology of this species is almost unknown, collected near to the sea level, but also to $2.253 \mathrm{~m}$ in Yemen, mostly at light, some specimen on Arundo donax, and in dry areas with halophyllous and xerophyllous low vegetation. Abdomen of the present specimens contained many fat drops, and the peritrophic membrane abundant fragments of adults and nymphs of Acari, Actinedida: Tarsonemidea: Tydeidae and Eriophyoidea: Tydeidae and Ereynetidae, and some pollen grains and fungi hyphae. The two female specimens subjectively assigned to this species have not fussed the lateral gonapophyses, as it is usual in the subgenus (Meinander 1972, 1981).

SENEGAL: Sali, $0 \mathrm{~m}, 25-27$. VIII. 2004, $2 \sigma^{\top} \sigma^{7}, 2$ 우 우 light, V. J. Monserrat.

Many species of subgenera Coniopteryx or Xeroconiopteryx have been recently described in the south Palaearctic and in the Afrotropical Regions (see recorded recent bibliography), sometimes on the basis of a single specimen, and sometimes with very slight differences among them and with some other previously described species. The use of characters as the kind and degree of esclerotization and shape limits of gonarcus or hypandrium in the male genitalia have been reported as very variable characters, and a complex nomenclatorial and taxonomic situation has been generated, with a very busy and difficult solution. For instance, and with no doubt, the species Coniopteryx (Coniopteryx) sclerotica described by Meinander (1998a) from a single male specimen from South Africa (Transvaal), collected in a garden of Pretoria, is the same species that Monserrat (1995) described as Coniopteryx (Coniopteryx) greenpeace also from gardens of the same city, and a new synonymy is now proposed:

Coniopteryx (Coniopteryx) greenpeace Monserrat, 1995: 121

= Coniopteryx (Coniopteryx) sclerotica Meinander, 1998a: 139 n. syn.

Respecting to the now recorded species: Coniopteryx (Xeroconiopteryx) ketiae seems very similar to Coniopteryx (Xeroconiopteryx) furcata described by Meinander (1998b) from a single specimen from Israel, but only new material will tell us if both are conspecific or not. However, the combination name Coniopteryx furcata was already used by Meinander (1983b) when he described a new species from Brasil, and because any available synonymy is known for this junior homonym, a new replacement name must be proposed for this primary homonym. In hope for a near and harmonic future where the Hebraic and Palestine People get live together we propose the name:

Coniopteryx (Xeroconiopteryx) conviventibus nom. nov. for Coniopteryx (Xeroconiopteryx) furcata Meinander,1998b: 25 nec Coniopteryx (Scotoconiopteryx) furcata Meinander, 1983b: 184.

\section{Coniopteryx (Xeroconiopteryx) triantennata Monserrat, 1995: 117 \\ = Coniopteryx (Xeroconiopteryx) sestertia Meinander, 1998a: 136 n. syn.}

A scarcely known species, described from South Africa (Transvaal), recorded from Zimbabwe, and collected at light and on unspecified arboreal vegetation.

The new northern records in west Africa (Senegal) suggest a wider south Saharan distribution for this species (Fig. 1). With some light differences with the South African specimens for the absence of the median ventro-distal projection of hypandrium in the males, these specimens agree 


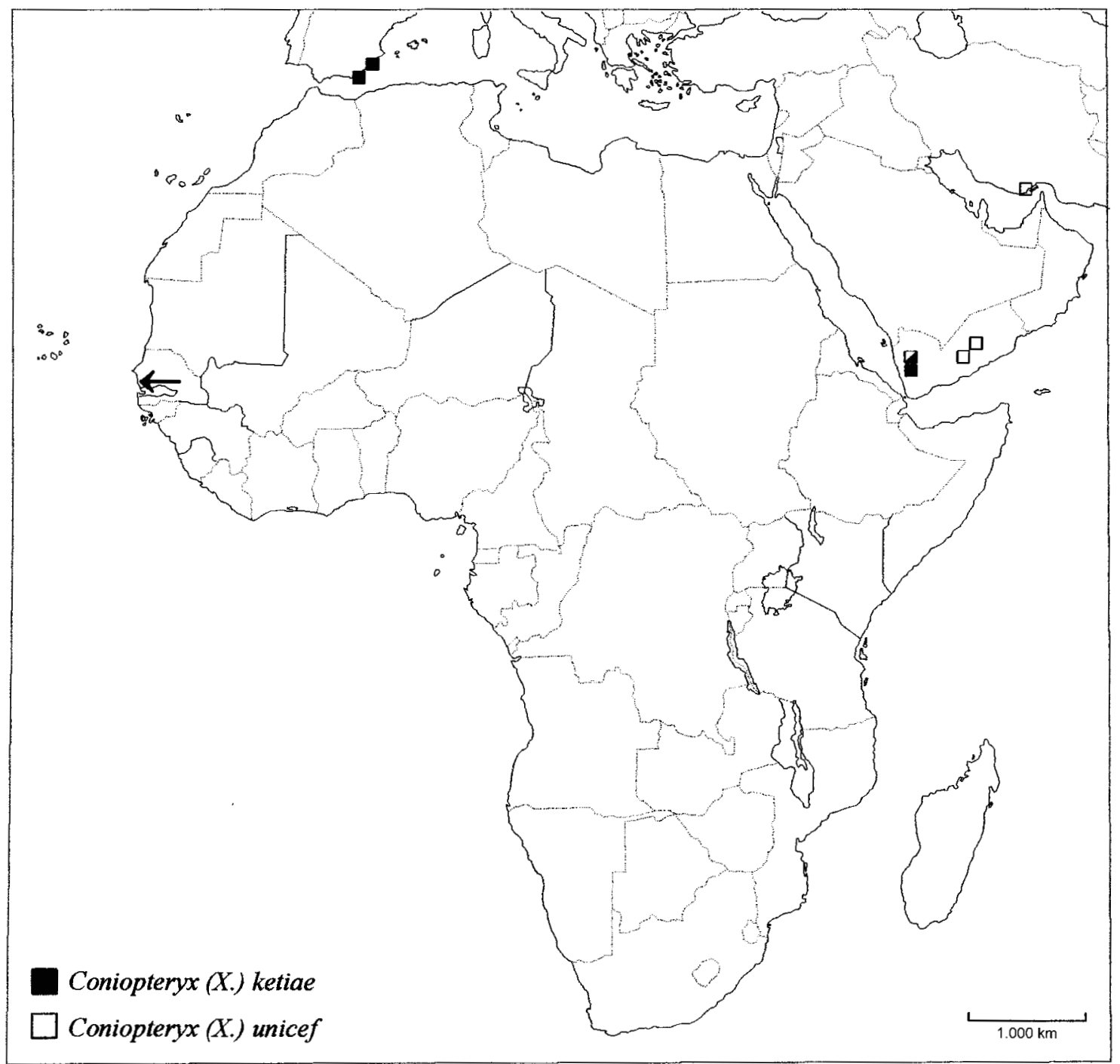

Fig. 3.- Previously known distribution of the SW palaearctic species now recorded in Senegal (arrow).

Fig. 3.- Distribución conocida de especies del suroeste paleártico colectadas en Senegal (flecha).

well with its peculiar and characteristic data given by Monserrat (1995). Number of flagellomers in male specimens: 24, 24, 24, 24.

As some other species previously proposed as synonymies, we think that Coniopteryx (Xeroconiopteryx) sestertia, described by Meinander (1998) from Botswana, is the same species that those we now refer, and a new synonymy is now proposed.

The abdomen of these specimens contained many fat drops, and the peritrophic membrane abundant fragments of adults and nymphs of Acari, Actinedida: Tydeidae and some pollen grains.

SENEGAL: Sali, 0 m, 25-27 August 2004, $50^{7} \sigma^{7}$ at light, V. J. Monserrat.

Coniopteryx (Xeroconiopteryx) unicef Monserrat, 1996

A scarcely known species described and recorded from Yemen, also recorded from Iran. It seems 
to be a very abundant species and it was recorded on Phoenix, Zizyphus and Citrus.

The new records in west Africa (Senegal) suggest a wide Saharan border distribution (Fig. 3). With some light differences in the shape of paramera in male specimens, these new African specimens agree well with the peculiar and characteristic data given by Monserrat (1996). Number of flagellomera in male specimens: 29, 29, 29, 30, and 23, $25,25,26$ in the female.

The peritrophic membrane of these specimens contained abundant fragments of adults and nymphs of Acari, Eriophyoidea: Rhyncaphytoptidae and some pollen grains.

SENEGAL: Sali, 0 m, 25-27 August 2004, 60 $0^{x}, 3$ 우 우 at light, V. J. Monserrat.

\section{Conwentziini Enderlein, 1905}

\section{Semidalis pluriramosa (Karny, 1924)}

An expansive circum Saharan species known from Egypt, Algeria, Sudan, Nigeria, Morocco, Tunisia, Mali, Zimbabwe and Zambia, extending to the dry and warm sub-desertic SE of the Iberian Peninsula and to Yemen (Fig. 2). The new west Saharan record closes on the west the circum Saharan circle for its distribution, already suggested by Monserrat \& Díaz Aranda (1990). The larva of this species was described by Monserrat, Díaz Aranda \& Hölzel (1991).

It is a species recorded on very different plant substrates (Eucalyptus, Citrus, Phoenix, Olea, Ceratonia, Amygdalus, Acacia, Dicrostochys, Zizyphus, Tamarix, Arundo, Vitellama, Combretum, Baissea, Brachystegia and Tetraclinis), also at light in dry areas, in a dry river-bed (with Tamarix galli$c a \&$ Arundo donax) and in very dry and saline plains (with halophyle plants as Chenopodiaceae), sometimes near to the sea level, but also to $1.700 \mathrm{~m}$.

SENEGAL: Sali, 0 m, 27 August 2004, $1 \sigma^{7}$ on Melia azedarach L. (Meliaceae) V. J. Monserrat.

\section{Semidalis deemingi Meinander, 1975}

Species described from Nigeria, known from a single specimen, and not subsequently recorded. The new specimens agree well with data noted by Meinander (1975a), and some first data on its plant substrate and biology is now contributed.

The abdomen of the present specimens contained many fat drops, and gut and the peritrophic membra- ne abundant fragments of Acari, Actinedida, Eriophyoidea: Tydeidae and Ereynetidae, fragments of unidentified insects, some pollen grains and fungi hyphae.

SENEGAL: Sali, 0 m, 27 August 2004, $80^{7} \sigma^{7}, 5$ 우 $ᄋ$ on Melia azedarach L. (Meliaceae) V. J. Monserrat.

Probably this species and Semidalis brincki Tjeder, 1957 (known from a single female specimen from Lesotho), Semidalis Enderleini Meinander, 1972 (known from a single male specimen from Tanzania), Semidalis fuelleborni Enderlein, 1906 (known from Angola, South Africa, Namibia, Botswana, Tanzania, Uganda, Zimbabwe and Zambia), Semidalis africana Enderlein, 1906 (known from Kenya, Tanzania, South Africa and Uganda) -last two very variable species (Meinander 1998a)- and even Semidalis arabica Meinander, 1977 (known from a single specimen from Yemen) may really be the same species. These questions on some African Semidalis problematic species were already reported by Meinander (1972, 1983a, 1990, 1996, 1998a), Monserrat (2002), etc., putting in doubt the validity of some of these species, even Semidalis deemingi Meinander, 1975. However, the now recorded new specimens seem to confirm the maintenance of the male characters in this southwest Saharan population, and probably Semidalis deemingi Meinander, 1975 could be a different and valid species (Fig. 1) and so it is now considered, but as Meinander (1998a) refers for another afrotropical species of this genus, a large variability series of the same taxon is not discarded.

\section{Conclusions}

The west African, and particularly the Senegal dusty wings fauna was almost unknown, and it has been particularly suggested as presumptively poor (Ohm \& Hölzel, 1984; Hölzel \& Ohm, 1990). However, and in spite of the inadequate sampled environment (touristy urbanized area) and the scarceness of samplings (mostly three nights samplings at light), the new contributed data suggest a great biodiversity (eight species) and a presumptive abundance (37 specimens) of dusty wings for this country/area, where nine dusty wings species are, at the present, recorded in Senegal.

The afrotropical elements seem to be more frequent and more abundant in Senegal (Fig. 1), but also expansive circum Saharan elements (Fig. 2) and SW. palaearctic elements (Fig. 3) are also present. The presence of both afrotropical and palae- 
arctic elements gives to this African area a great richness, a great similarity, and a comparable abundance of taxa found in the opposite east Afrotropical area (Southern Arabian Peninsula) where also the limits of the Palaearctic and Afrotropical Regions join (Meinander 1977, 1979; Monserrat 1996; Sziráki 1992, 1997, 1998; Aspöck et al., 2001).

Some of the now recorded data confirm the wide dispersion and the ample geographical distribution of many African dusty wings species (Meinander, 1990, 1996, 1998a), as it also occurs in other biogeographical regions as the Palaearctic or Neotropical.

A very wide distribution is currently accepted in some of the well known palaearctic dusty wings species, with some one distributed from Morocco to Afghanistan, from the Canary Islands to Japan or from the Iberian Peninsula to Mongolia (Meinander 1972, 1990; Aspöck et al., 1980, 2001, etc.), but a clear tendency to describe new taxa is observed in more "exotic" samples or countries, and descriptions of future new species in the Afrotropical Region must take into account this question.

Also, a certain degree of morphological variability is usually accepted in many of the well known palaearctic dusty wings species, especially in those with a wider geographical distribution (Meinander $1972,1990,1992)$, but this criterion "seems do not affect too much" when the studied material comes from "exotic" countries, and an effort must be made in this way. This variability question was already reported for other palaearctic species, and also for some afrotropical species by Meinander (1998a), and it also would be taken into account when new species are described, specially if descriptions are based on a single specimen, trying to avoid (as very frequently occurs) that authors give excellent morphological descriptions of the new taxa, but very poorly discussed. Obviously it also affects to oriental and neotropical dusty wings new studies.

At last, the biology of the most of afrotropical dusty wings species is far to be well known, but the frequent presence of rests of mites (especially Acari: Actinedida, Eriophyoidea, Tarsonemidea) in the gut of the present specimens confirm the potential of the dusty wings as biological controllers of such pests.

\section{ACKNOWLEDGEMENTS}

We want to manifest our gratefulness to Luis S. Subías for identifying the mites, to David Papenberg, Gloria Santos and
Eduardo Ruiz for help us making the figures, and to Teófilo Gómez-Calcerrada for reading the English manuscript.

\section{References}

Aspöck, H., AsPöck, U. \& Hölzel, H., 1980. Die Neuropteren Europas. Goecke \& Evers. Krefeld. t. 1: 495 pp., t. 2: 355 pp.

AsPÖCK, H. \& HöLzEL, H., 1996. The Neuropteroidea of North Africa, Mediterranean Asia and of Europe: a comparative review (Insecta). Proceedings of the Fifth International Symposium on Neuropterology. Toulouse: 31-86.

AsPöCK, H., Hölzel, H. \& AspöCK, U., 2001. Kommentierter Katalog der Neuropterida (Insecta: Raphidioptera, Megaloptera, Neuroptera) der Westpaläarktis. Denisia. Linz. 606 pp.

EndERLEIN, G., 1906. Monographie der Coniopterygiden. Zoologische Jahrbücher. Abteilung für Systematik, Geographie und Biologie der Tiere, 23: 173-242, pl. 4-9.

ENDERLEIN, G., 1914. Ueber zwei neue afrikanische Coniopterygiden. Bolettino del Laboratorio di Entomologia Agraria di Portici 8: 225-227.

HöLzEL, H., 1998. Zoogeographical features of Neuroptera of the Arabian peninsula. Acta Zoologica Fennica, 209: 129-140.

Hölzel, H. \& OHM, P., 1990. Verbreitung und Phänologie kapverdischer Neuropteren (Insecta: Planipennia). Courier Forschungsinstitut Senckenberg, 129: 139145.

Hölzel, H., OHM, P. \& Duelli, P., 1999. Contribution to the knowledge of the Neuroptera of Ethiopia. Entomofauna, 20(21): 345-372.

McEwen, P., New, T. R. \& Whittington, A. E., 2001. Lacewings in the Crop Environment. Cambridge University Press. Cambridge. 546 pp.

Meinander, M., 1972. A Revision of the family Coniopterygidae (Planipennia). Acta Zoologica Fennica, 136: 1-357.

Meinander, M., 1975a. Coniopterygidae from West Africa (Insecta: Neuroptera). Entomologica Scandinavica, 6: 247-252.

MeinAnder, M., 1975b. Coniopterygidae from South Africa (Neuroptera). Notulae Entomologicae, 55: 8185.

MeinAnder, M., 1976. Coniopterygidae from Africa (Neuroptera). Notulae Entomologicae, 56: 85-88.

Meinander, M., 1977. Coniopterygidae from the Arabian Peninsula (Neuroptera). Entomologica Scandinavica, 8: 81-85.

MeinAnder, M., 1979. Insect of Saudi Arabia, Neuroptera: Fam. Coniopterygidae. Fauna of Saudi Arabia, 1: 334-341. 
MEINANDER, M., 1981. A review of the genus Coniopteryx (Neuroptera, Coniopterygidae). Annales Enomologici Fennici, 47: 97-110.

Meinander, M., 1982. The Coniopterygidae of Ceylon (Neuroptera). Entomologica Scandinavica, 13: 49-55.

MeInANDER, M., 1983a. The Coniopterygidae (Neuroptera) of southern Africa and adjacent Indian Ocean Islands. Annals of the Natal Museum, 25(2): 475-499.

Meinander, M., 1983b. Coniopterygidae from South and Central America II (Neuroptera). Neuroptera International, 2(4): 179-198.

MEINANDER, M., 1990. The Coniopterygidae (Neuroptera, Planipennia). A check-list of the species of the world, descriptions of new species and other new data. Acta Zoologica Fennica, 189: 1-95.

Meinander, M., 1992. A review of the family Coniopterygidae (Insecta: Neuroptera). Proceedings of the Fourth International Symposium on Neuropterology, Toulouse: $255-260$.

Meinander, M., 1996. Coniopterygidae from subSaharan Africa. Proceedings of the Fifth International Symposium on Neuropterology, Toulouse: 187-192.

MEINANDER, M., 1998a. Coniopterygidae (Neuroptera) from southern and eastern Africa. African Entomology, 6(1): 117-146

Meinander, M., 1998b. Coniopterygidae (Neuroptera) from the Mediterranean Region and Iran. Journal of Neuropterology, 1: 23-31.

Monserrat, V. J., 1985a. Contribución al conocimiento de los neurópteros de Marruecos (Insecta, Neuroptera, Planipennia). Mediterránea (Serie Biologica), 8: 7382.

Monserrat, V. J., 1985b. Nuevos datos sobre los Coniopterígidos (Neur., Plan., Coniopterygidae) ibéricos. Boletín de la Asociación española de Entomología, 9: 127-141.

Monserrat, V. J., 1989. Contribución al conocimiento de los Coniopterígidos de Río Muni (Guinea Ecuatorial) (Neuropteroidea, Planipennia: Coniopterygidae). Annali del Museo Civico di Storia Naturale di Genova, 87: 157-181.

Monserrat, V. J., 1995. Nuevos datos sobre los coniopterígidos de las regiones Paleártica y Afrotropical. (Neuroptera: Coniopterygidae). Graellsia, [1994], 50: 109-127.

MonSERrat, V. J., 1996. Nuevos datos sobre los coniopterígidos de Yemen (Neuroptera: Coniopterygidae). Annali del Museo Civico di Storia Naturale di Genova, 91: 1-26.

Monserrat, V. J., 1998. Nuevos datos sobre los coniopterígidos de Zimbabwe y Zambia (Neuroptera:
Coniopterygidae). Journal of Neuropterology, 1: 515.

Monserrat, V. J., 2002. New data on the dusty wings from Africa and Europe (Insecta, Neuroptera: Coniopterygidae). Graellsia, 58(1): 3-19.

Monserrat, V. J. \& DíAZ-Aranda L. M., 1988. Contribución al conocimiento de los coniopterígidos de la Isla de Bioco (Guinea Ecuatorial) (Neuropteroidea, Planipennia: Coniopterygidae). Revue de Zoologie Africaine, 102: 493-502.

Monserrat, V. J. \& DíAZ-Aranda L. M., 1990. Nuevos datos sobre los coniopterígidos ibéricos (Neuroptera: Coniopterygidae). Neuroptera International, 6(1): 39-49.

Monserrat, V. J., Díaz-Aranda L. M. \& Hölzel, H., 1991. Contribución al conocimiento de los neurópteros de Marruecos (Insecta, Neuropteroidea). Eos 66(2): 101-115.

New, T. R., 1989. Planipennia, Lacewings. In: Walter de Gruyter (ed.). Handbuch der Zoologie, Vol. (4)30, Berlin und Leipzig. $129+$ XI pp.

OHM, P. \& Hölzel, H., 1984. Zur zoogeographie der Neuropteren auf den Mittelatlantischen Inseln eine erste übersicht (Insecta: Planipennia). Courier Forschungsinstitut Senckenberg, 71: 79-86.

OHM, P. \& HöLzel, H., 1997. Beitrag zur Kenntnis der Neuropterenfauna der Maskarenen (Neuroptera: Coniopterygidae, Hemerobiidae, Chrysopidae, Myrmeleontidae). Entomofauna, 18(17): 221-236.

OHM, P. \& Hölzel, H., 1998. A contribution to the knowledge of the neuropterous fauna of the Comoros: The Neuroptera of Mayotte. Acta Zoologica Fennica, 209: 183-194.

Онм, P. \& HöLzel, H., 1999. Die ConiopterygidenGattung Semidalis Enderlein auf den Mittelatlantischen Inseln (Neuropteroidea: Planipennia: Coniopterygidae). Reichenbachia, 33(30): 231-237.

SzIRÁki, G., 1990. Two Aleuropteryx species from Tanzania (Planipennia: Coniopterygidae). Folia Entomologica Hungarica, 51: 117-121.

SzIRÁKI, G., 1992. Coniopterygidae from Yemen (Neuroptera). Acta Zoologica Academiae Scientiarum Hungaricae, 38(1-2): 89-94.

SzIRÁKI, G., 1994. Coniopterygidae from the Afrotropical Region (Neuroptera). Acta Zoologica Academiae Scientiarum Hungaricae, 40(2): 171184.

SzIRÁKI, G., 1997. Data to the Coniopterygid fauna of Yemen, with description of twelve new species (Neuroptera: Coniopterygidae). Acta Zoologica Academiae Scientiarum Hungaricae, 43(3): 271294.

SzIRÁKI, G., 1998. Zoogeographic relations of South Asian coniopterygids (Neuroptera, Coniopterygidae). Acta Zoologica Fennica, 209: 249-254. 
SzIRÁKI, G. \& Greve, L., 1996. Some Coniopterygidae (Neuroptera) from a mountain rainforest of Tanzania Acta Zoologica Academiae Scientiarum Hungaricae, 42(1): 81-88.

TJEDER, B., 1957a. Neuroptera from the Cape Verde Islands. 1. Fam. Coniopterygidae. Commentationes Biologicae Societas Scientiarum Fennica, 16(8): 1-11.

TJEDER, B., 1957b. Neuroptera-Planipennia. The Lace wings of Southern Africa. 1. Introduction and Families Coniopterygidae, Sisyridae, and Osmylidae.
In: P. Brinck. \& G. Rudebec (eds.). South African Animal Life, vol. 6. Swedish Natural Science Research Council. B. Hanström. Stockholm: 95-188.

Recibido, 19-IX-2005

Aceptado, 20-IV-2006

Publicado, 30-VI-2006 